\title{
FORAGE PARTICLE SIZE: IT'S IMPLICATIONS ON BEHAVIOR, PERFORMANCE, HEALTH AND WELFARE OF DAIRY COWS
}

\author{
Emran HOSSAIN \\ Professor and Head, Department of Animal Science and Nutrition, Faculty of Veterinary Medicine, Chattogram Veterinary and \\ Animal Sciences University, Zakir Hossain Road, Khulshi, Chattogram-4225, Bangladesh \\ ¿Email: emran@cvasu.ac.bd; (1) orciD: 0000-0002-1750-7284
}

\begin{abstract}
Forage particle size has long been recognized as the key intricate factor determining ration contents of physically effective neutral detergent fibre, which in recent years has become the most important consideration in advanced dairy feed formulation for the rumen health, milk yield and welfare of the dairy cows. Fine chopping reduces particle size, resulting in reduced forage dry matter intake, lower retention period of digesta, decreased digestibility of fiber, inconsistent quality of ruminal mat, decreased milk yield, depression of milk fat, and health issues secondary to sub-acute ruminal acidosis. Similarly, excessive coarse forage particles may be lead to reduced total nutrient intake, poor digestibility of organic matter, reduced milk yield and quality, and compromised overall performance. The rumen is a constant fermentation vessel, containing vast amounts of hydrogen ions that can only be stabilized by a proper salivary buffer balance obtained through intake of sufficient effective neutral detergent fibre and its optimal duration. The overall impacts of particle size, however, depend on forage type, forage to concentrate ratio and, fermentability characteristics of the organic matter in the formulated ration. In general, 8-19 $\mathrm{mm}$ particle size irrespective of forage type measured on Penn State Particle Separator may be considered optimum for practical dairy feed formulation.
\end{abstract}

Keywords: Dairy cattle, Forage particle size, Health, Milk yield, Performance.

\section{INTRODUCTION}

Forage particle size (FPS) or chop length (CL) has long been recognized as one of the principal factors influencing feed intake (Haselmann et al., 2019), feed sorting behavior (Jiang et al., 2018), digestibility of feed (Zhao et al., 2020), rumination (Deswysen et al., 1978), turnover kinetics of rumen metabolites (Storm and Kristensen, 2010), rumen pH (Kmicikewycz and Heinrichs, 2015), microbial protein synthesis (Rodríguez-Prado et al., 2004), milk yield (Havekes et al., 2020), milk fat content (Sharifi et al., 2012), profile of milk fatty acid (Thomson et al., 2017), milk protein percent (Nasrollahi et al., 2015) and overall, cow health (Havekes et al., (2020). The ruminant diet is dominant in crude fibre which is inevitable for their health, productivity and welfare. The rumen appears to be a continuous fermentation vat that produces large quantities of hydrogen ions $(60,000 \mathrm{mEq} /$ day or more) (Allen, 1997). Thus, upkeep of stable ruminal $\mathrm{pH}$ is intricate. The ruminal $\mathrm{pH}$ is in equilibrium by two key factors: an appropriate balance of slowly and rapidly fermentable carbohydrates and adequate physical fiber to stimulate chewing activity and saliva production (Allen, 1997). Fine chopping reduces FPS and thus can decreases the physically effective neutral detergent fibre (peNDF) contents of diet (Stojanović et al., 2013). The peNDF contents of diet, thus, virtually results from the interaction between the contents of chemical fiber and forage chop size in the diet (Gümüş and Bayram, 2020). The shorter than the optimum FPS may result in low dry-matter intake, decreased fiber digestibility, decreased milk yield, milk fat depression, and health problems secondary to sub-acute ruminal acidosis. Similarly higher than recommended FPS may provoke feed sorting, spending excessive time for re-chewing, higher retention time of digesta and reduced fractional passage kinetics of particulates. This review, therefore, aims to highlight the link between FPS and peNDF contents of the rations and their subsequent buffering implications on production, health, efficiency of nutrient utilization, and welfare of the dairy animals and explains why not too long, not too short, but "just right" FPS is required for dairy cows.

\section{BEHAVIOR}

\section{Feed sorting}

Twenty Holstein bull calves were exposed in the total mixed rations to observe the effect of early introduction to rations varying in FPS on the progression of feed sorting in dairy calves (Miller-Cushon et al., 2013). Calves offered the low FPS diet consumed less neutral detergent fiber as a level of anticipated intakes and would in general consumed less acid detergent fiber and more non-fiber sugars, than the calves recently fed the high FPS diet. It showed that calves recently fed the low FPS diet were sorting for concentrate and this sorting behavior might have been influenced by their early involvement in the rations varying in FPS. Similarly, twelve multiparous lactating Holstein dairy animals were exposed in a 
replicated $4 \times 4$ Latin square design with a $2 \times 2$ factorial arrangement to decide the impacts of FPS on feed sorting behavior. As a rule, sorting activity decreased with reduced forage particle size. In any case, the dairy animals fed high quality forage had a lower sorting activity and higher production performance than those who fed low-quality forage (Jiang et al., 2018). In another study, larger FPS forages increased sorting behavior (Figure 1); however, had no impact on rumen fermentation or chewing behavior of the animal (Suarez-Mena et al., 2013). In another experiment (Leonardi et al., 2005), the consequences for feed sorting of various amounts, characteristics, and lengths of alfalfa feed were tried, without changing the extent of concentrate in the eating regimens. These investigators found that the dairy animals increased their sorting activity with more hay and with longer hay, though the quality of feed had no impact. Similar impacts of particle size have been demonstrated by other investigators (Kononoff and Heinrichs, 2003).

Despite the fact that few scientists have indicated that sorting against long particles and NDF can be decreased by changing the quality of forages inside a TMR (Kononoff and Heinrichs, 2003) nobody has clearly explained how do the extent of forage in the eating regimen impacts sorting behavior. It was demonstrated that animals effectively opposed long particles, NDF, and peNDF, and chose for short particles when taken care of a long forage diet. This finding negates the speculation that animals would sort more with increased forage in the eating regimens. It was accepted that animals would be exceptionally energetic to sort for the concentrate part of their TMR, particularly when accessibility of concentrate was restricted. Accordingly, it was accepted that decreasing the concentrate divided in the TMR would propel dairy cows to sort for the concentrate and against forage (Voelker et al., 2002). The increased sorting of the long forage diet demonstrated, in any case, that a ration with higher extent of concentrate might be all the more effectively sorted, essentially in light of the fact that the concentrate content is progressively available than the roughages.

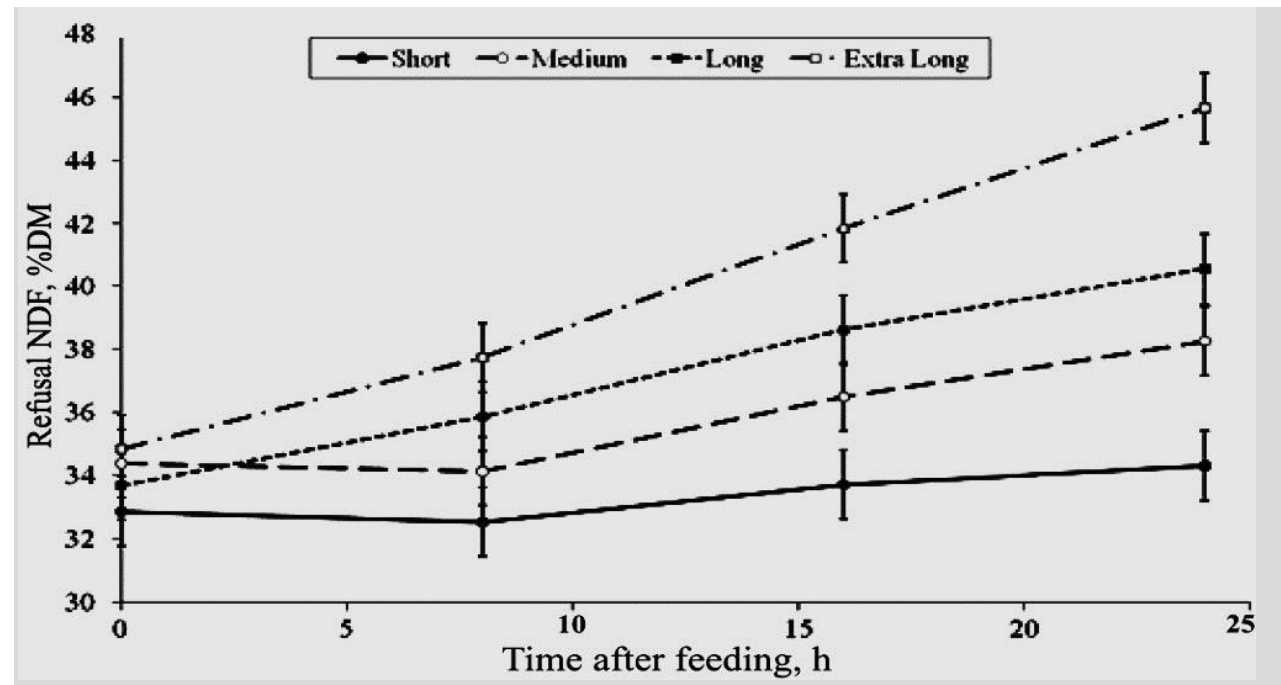

Figure 1 - Effects of forage particle size on feed sorting in dairy cows (Maulfair et al., 2010). The TMR contains short (1.5 $\mathrm{mm})$, medium $(6.5 \mathrm{~mm})$, long $(8.6 \mathrm{~mm})$, and extra-long $(11.7 \% 26.9 \mathrm{~mm})$ particles.

\section{Chewing and rumination}

Forage size affects both eating and chewing time (Table 1; Figure 2). Rumination time decreased from 504 to 400 $\mathrm{min} / \mathrm{d}$ for cows expending short particle size contrasted with long particle size. Similarly, chewing was decreased from 702 to $570 \mathrm{~min} / \mathrm{d}$ when dairy animals consumed short particle size (Ramirez Ramirez et al., 2016). In a different study, forty-eight Holstein calves were arbitrarily distributed in a $2 \times 2$ factorial plan to examine the impacts of FPS on sorting behavior of dairy calves fed texturized concentrates (Omidi-Mirzaei et al., 2018). Calves fed forage with long FPS invested more energy for rumination, eating forage, and invested less time lying and non-nutritive oral practices than medium particle size. Essentially, the cows decreased eating and ruminating time by 4.8 and 1.9 min, respectively per kilogram of DMI and demonstrated lower rumination endeavors while fed low FPS diet (Haselmann et al., 2019). Thus, increased chewing and rumination because of elevated FPS is predictable.

Table 1 - Influence of forage physical form on chewing activity

\begin{tabular}{|c|c|c|c|}
\hline Item & Long & Chopped & Pelleted \\
\hline Eating, $\min / \mathrm{d}$ & $196^{a}$ & $174^{a}$ & $128^{b}$ \\
\hline \multicolumn{4}{|l|}{ Ruminating } \\
\hline $\min / d$ & $383^{a}$ & $398 a$ & $61^{b}$ \\
\hline min/kg NDF intake & $64.1^{a}$ & $64.4^{a}$ & $10.2^{b}$ \\
\hline \multicolumn{4}{|l|}{ Total chewing } \\
\hline $\min / d$ & $579^{a}$ & $572^{\mathrm{a}}$ & $189^{b}$ \\
\hline min/kg DM intake & $29.2^{a}$ & $28.6^{a}$ & $9.8^{b}$ \\
\hline
\end{tabular}




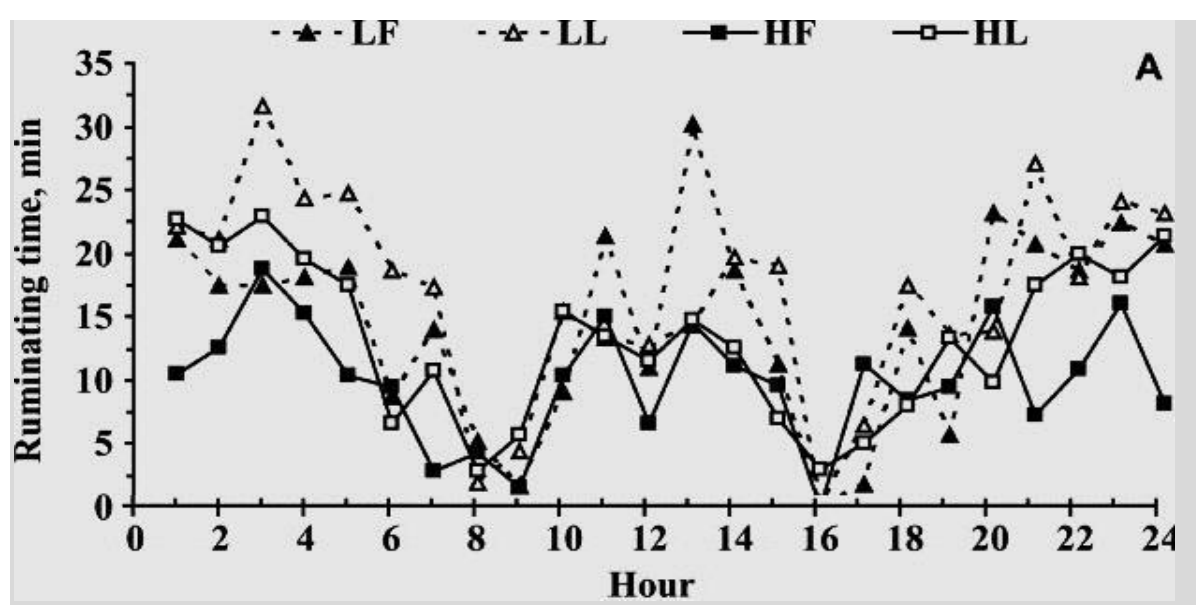

Figure 2 - Relationship between forage particle size and ruminal pH (Zebeli et al., 2007). LF = low concentrate level and fine hay; LL = low concentrate level and long hay; HF = high concentrate level and fine hay; $\mathrm{HL}=$ high concentrate level and long hay.

\section{Ruminal mat consistency}

Particle size legitimately influences the rumen mat, which is shaped by little particles holding adherence of the longer-stem forages that float in the rumen. This connection permits the smaller particles to stay suspended in the rumen to be appropriately fermented. Without adequate fiber, particles may sink into the less-desirable sites of the rumen where they cannot be digested properly. Thus, the benefits of high FPS is likely for better mat consistency.

\section{Retention time of digesta}

Rumen fill can physically constrain the retention time of digesta in dairy cows in forage-based eating regimens with high FPS (Shaver et al., 1988). Feed residues normally do not get away from the rumen either by a decrease or by the restricted entry of additional intake. In spite of the fact that the impacts of the rate of particle size decrease on ruminal retention time is not consistent, nevertheless, it was recommended that the rumen comprises of a rumination pool of larger particles that cannot go through the reticulo-omasal orifice until arrive at a smaller particle size (Ternouth, 1968). In light of this rate restricting particle size decrease hypothesis for particulate passage, it was recommended that the higher FPS will lengthen retention time (Figure 3 and 4) and the other way around (Poppi et al., 1980). Detailed information is minimal about the distribution of particle size at different locations within the reticulo-rumen, abomasum and intestines. However, coarse particles were more abundant in the dorsal than ventral rumen, which decreased with time after eating, it was observed (Evans et al., 1973). This variable distribution of the small particle pool coupled with small variations in high and low FPS chewing behavior may raise the question as to the role of reducing particle size in the rumen particle passage. For low and high fiber forages, the large proportion of small particles in the lumen suggests that the rate of escape of small particles from the rumen is an important factor determining the retention time of the rumen. In relation to the longer retention time of the large particle itself, the effect that larger particles have greater retention time in the rumen may be due to their effect on the forming of the rumen mat and eventual trapping of small particles (Shaver et al., 1988).

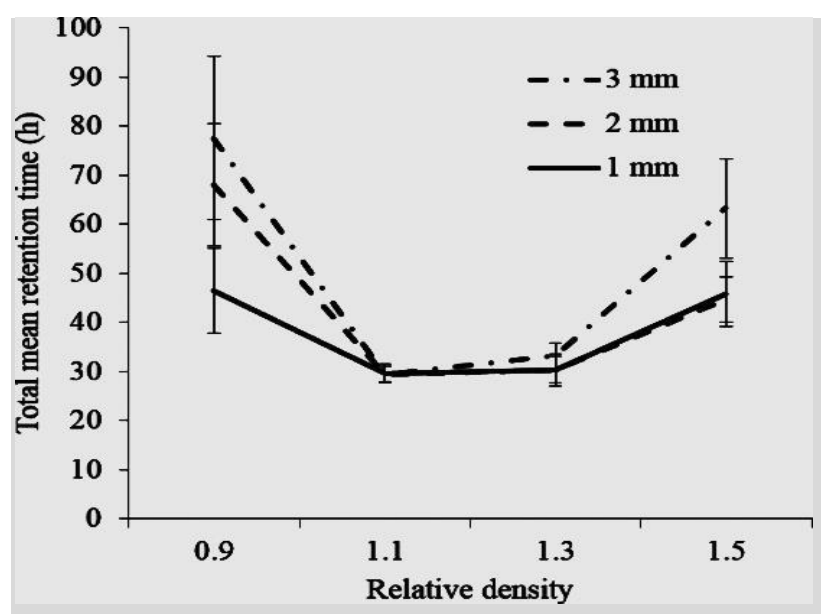

Figure 3 - Influence of relative density (0.9-1.5) and diameter $(1-3 \mathrm{~mm})$ on total mean retention time in the entire digestive tract (Dufreneix et al., 2019).

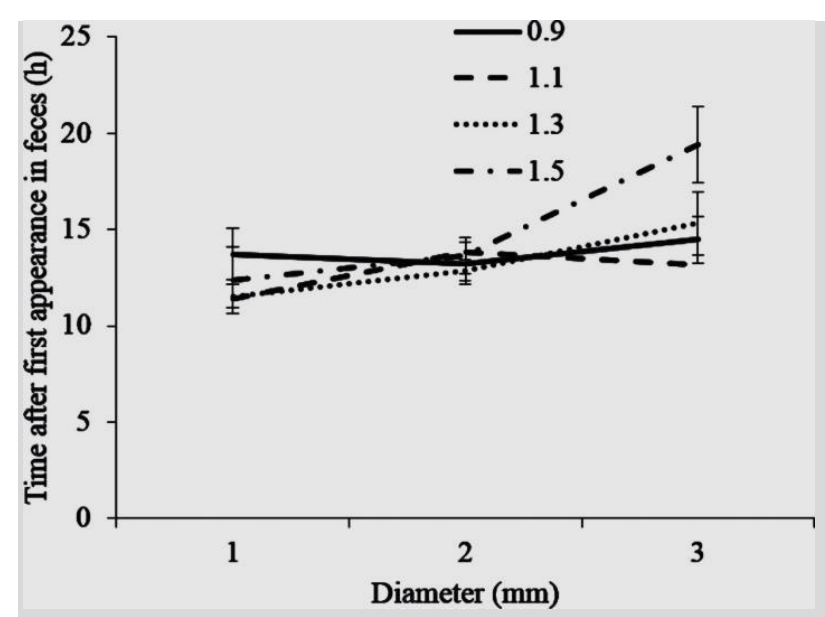

Figure 4 - Influence of relative density (0.9-1.5) and diameter (1-3 $\mathrm{mm}$ ) of plastic particles on the time until they first appear in the feces (Dufreneix et al., 2019). 


\section{PERFORMANCE}

\section{Dry matter intake}

Overall, type and nature of the feed, body condition score, health, sex, age, equality of animal, milk yield, milk composition, environmental temperature, and humidity are the most dependable indicators influencing dry matter intake (DMI; Table 1) in dairy animals (Méndez et al., 2020). Explicit impacts of FPS on DMI are scant. The impact of FPS on DMI in dairy animals was assessed utilizing a meta-analysis with 46 papers and 28-91 preliminaries of published information from the literature (1998-2014). It was obvious that DMI improved because of bringing down the impact of FPS containing silage however not hay (Nasrollahi et al., 2015). In another study, the peNDF substance of dairy cattle diets was changed by differing levels of FPS of alfalfa silage (Li et al., 2020). Expanding peNDF substance of diets by expanding FPS decreased DMI. Therefore, the expansion in DMI because of decreased FPS was noteworthy in animals taken care of wild-rye feed diets (Jiang et al., 2018). In another study, the effects of physical form and stage of maturity at harvest of whole-crop barley silage on feed intake in dairy steers were evaluated in a $4 \times 4$ Latin square design (Rustas et al., 2010). It was assumed that, chopping increased DMI when grain was collected at the dough stage however not at the peak phase of maturity (Rustas et al., 2010). Decreasing the corn silage chop length increased dry matter intake ranging 22.3$23.2 \mathrm{~kg} / \mathrm{d}$, at 4 to $5 \mathrm{~h}$ in the wake of intake or milk production (Bhandari et al., 2008). The decrease in FPS increased DM consumption from 19.4 to $20.1 \mathrm{~kg} / \mathrm{d}$ at the elevated level of concentrate and from 16.9 to $17.7 \mathrm{~kg} / \mathrm{d}$ at the low degree of concentrate (Einarson et al., 2004).

Despite the fact that, sorting practices because of inconsistencies in FPS typically hinder the eating rate, yet again inverse evidence was demonstrated (DeVries et al., 2007). It was accounted for that, dairy animals consuming the long forage diet consumed at a more prominent rate and in a shorter time span. Johnson and Combs (1992) additionally found that cows consuming a half forage diet invested less energy eating than those fed a $74 \%$ forage diet. Conversely, Voelker et al. (2002) revealed comparable intake times for cows fed a 67 or $44 \%$ forage diet. These last researchers proposed that such inconsistencies in intake times might be the aftereffect of contrasts in dietary particle size. However,, neither of these past studies revealed dietary particle size. Strikingly, Voelker et al. (2002) reported that the eating time per kilogram of DMI was lesser for the animals taken care of a $44 \%$ forage diet, showing that these dairy animals consumed their DM quicker, like the more noteworthy intake rates on the long forage diet found in the current study. Allen (2000) expressed that the dietary factors that expansion eating time could decrease the time accessible for ruminating, in this way expanding the filling impact of the diet. Similarly, in this study, the high forage diet spent more time to be consumed, likely due to its high NDF substance and longer particle size. These variables may have added to an increased filling impact, representing the lower DMI on the high forage diet. Johnson and Combs (1992) noticed DMI as lower on their higher forage diets.

\section{Forage degradability}

Digestibility of dry matter or organic matter is improved when long forage particles are chopped but not ground (Tables 2 and 3). The impacts of FPS on degradability of individual amino acid (AA) in the digestive tract of lactating dairy cows with ruminal and duodenal cannulas were estimated in a Latin square design (Zhao et al., 2020). Degradability of most individual AA in the rumen was not influenced by FPS. In another study, the low FPS diet altogether increased total tract digestibility of the supplements (Haselmann et al., 2019). Chopping the dough stage silage decreased the extent of grain in defecation from 97 to $43 \mathrm{~g} / \mathrm{kg}$ DM demonstrating higher starch digestibility (Rustas et al., 2010). However, expanding FPS had no impact on AA supply however the digestibility of individual AA in the digestive tract changed significantly (Li et al., 2012). Total tract absorption of dietary NDF was decreased for fine-handled corn silage contrasted and control corn silage and coarse-prepared corn silage (28.4\% versus 33.9 and $33.7 \%$, respectively). Processing corn silage improved starch digestibility (Bal et al., 2000). It was accounted for that changing the forage particle size from 6 to $30 \mathrm{~mm}$ in a low-concentrate diet substantially increased the rumination time and ruminal mat consistency without influencing ruminal fermentation and passage. Further, particle breakdown and consistency of mat in the rumen increased, and in situ feed dry matter degradability improved, which thus demonstrated a higher capacity of ruminal digesta to degrade fiber (Zebeli et al., 2008).

\section{Fractional passage kinetics}

Long particle size feeding lowered the rate of dry matter passage from 3.38 to $2.89 \pm 0.42$ percent/h; mean retention time rose concomitantly from 31.7 to $38.4 \pm 5.36 \mathrm{~h}$ for long particle size diets (Ramirez Ramirez et al., 2016).

\section{Feed efficiency}

Twelve multiparous lactating Holstein animals were exposed in a replicated $4 \times 4$ Latin square design with a $2 \times 2$ factorial arrangement to decide the impacts of forage source and size of particle size on feed sorting, milk production and supplement digestibility in lactating dairy cows. The experiment featured that, feed efficiency (4\% fat-adjusted milk/DMI) improved from 1.18 to 1.11 when FPS decreased independent of forage source (Jiang et al., 2018).

\section{Milk yield}

An increased DMI is associated with increased milk yield (Table 5). Thus, increasing peNDF content of diets by increasing F:C ratio may decrease milk yield due to decreased DMI (Li et al., 2020). In an exhaustive meta-study, milk production reliably increased $(0.541 \mathrm{~kg} / \mathrm{d}$; heterogeneity $=19 \%)$ and milk protein production increased $(0.02 \mathrm{~kg} / \mathrm{d}) \mathrm{as}$ 
FPS decreased, however FCM was not influenced by FPS (Nasrollahi et al., 2015). FPS influences chewing activities and production of milk fat precursors in the rumen and modified milk fat substance and yield of fat-corrected milk (Lu, 1987).

\section{Table 2 - Intake and digestion of organic matter and acid detergent fiber (Firkins et al., 1986).}

\begin{tabular}{|c|c|c|c|c|}
\hline Forage size & Long & Chopped & Ground & SEM \\
\hline Organic matter intake (kg/day) & 13.2 & 12.6 & 13.1 & 0.11 \\
\hline Apparent digestion (\% of intake) in total tract) & 53.7 & 54.3 & 54.7 & 2.11 \\
\hline \multicolumn{5}{|l|}{ Apparent digestion (\% of intake) in rumen } \\
\hline Apparent & $28.1^{a}$ & $31.2^{a}$ & $20.8^{b}$ & 2.62 \\
\hline True & 57.7 & 56.0 & 55.3 & 4.32 \\
\hline Percent of apparent digestion in the rumen & $52.3^{a}$ & $57.4^{a}$ & $38.0^{b}$ & 2.92 \\
\hline Acid detergent fiber intake (kg/day) & 4.8 & 5.0 & 4.3 & 0.32 \\
\hline Apparent digestion (\% in take) in total tract & $36.7 \mathrm{c}$ & $39.7^{c}$ & $24.0^{d}$ & 2.67 \\
\hline Apparent digestion (\% intake) in rumen & $36.0^{c}$ & $35.6^{c}$ & $16.2^{\mathrm{d}}$ & 3.10 \\
\hline Percent of total digestion occurring in the rumen & $98.0^{\mathrm{a}}$ & $89.7^{a}$ & $67.5^{b}$ & 3.21 \\
\hline
\end{tabular}

Table 3 - Intake and digestion of nitrogen and partition of duodenal N flow.

\begin{tabular}{|c|c|c|c|c|}
\hline Forage size & Long & Chopped & Ground & SEM \\
\hline $\mathrm{N}$ intake (g/day) & $422 a$ & $322^{b}$ & $409^{a}$ & 9.3 \\
\hline \multicolumn{5}{|l|}{ Non-ammonia nitrogen flow at duodenum } \\
\hline g/day & $405^{c}$ & $337^{d}$ & $462^{e}$ & 27.0 \\
\hline$\%$ of $\mathbf{N}$ intake & $96^{c}$ & $103^{\mathrm{cd}}$ & $112^{\mathrm{d}}$ & 4.67 \\
\hline Feed and endogenous $\mathbf{N}$ & $37.2^{c}$ & $37.5^{c}$ & $46.8^{d}$ & 3.46 \\
\hline g/day & $157^{\mathrm{cd}}$ & $124^{c}$ & $194^{d}$ & 14.0 \\
\hline$\%$ of $\mathrm{N}$ intake & $37.2^{c}$ & $37.5^{c}$ & $46.8^{d}$ & 3.46 \\
\hline \multicolumn{5}{|l|}{ Bacterial $\mathbf{N}$ at duodenum } \\
\hline g/day & $248^{\mathrm{cd}}$ & $212^{c}$ & $269^{d}$ & 13.6 \\
\hline g/kg OM TROMD* & $32.5^{c}$ & $30.7^{c}$ & $37.5^{d}$ & 2.39 \\
\hline Post-ruminal N digestion $\mathrm{g} /$ day & $246 a$ & $203^{a}$ & $334^{b}$ & 25.7 \\
\hline Apparent $\mathrm{N}$ digestion in total tract, \% of $\mathrm{N}$ intake & $5.9^{c}$ & $58.3^{c}$ & $68.5^{d}$ & 2.39 \\
\hline
\end{tabular}

Table 4 - Ruminal kinetics in steers fed chopped or ground hay.

\begin{tabular}{|c|c|c|}
\hline Item & Chopped & Ground \\
\hline Ruminal particulate dilution rate, $\% / \mathrm{h}$ & 4.73 & 4.72 \\
\hline Ruminal fluid dilution rate, $\% / \mathrm{h}$ & 1034 & 10.64 \\
\hline Duodenal fluid flow, liters/dc & 78.8 & 76.5 \\
\hline Ruminal fluid volume, litersc & 78.1 & 67.7 \\
\hline Ruminal $\mathrm{NH}_{3}, \mathrm{mg} / \mathrm{dl}$ d & 14.0 & 15.6 \\
\hline Total ruminal volatile fatty acid concentration, $\mathrm{mM}$ & 76.1 & 77.5 \\
\hline Acetate, $\mathrm{mol} / 100 \mathrm{molc}$ & 71.5 & 71.2 \\
\hline Propionate, $\mathrm{mol} / 100 \mathrm{~mol}$ & 16.9 & 16.6 \\
\hline Buryrate, $\mathrm{mol} / 100 \mathrm{molc}$ & 9.5 & 9.8 \\
\hline
\end{tabular}




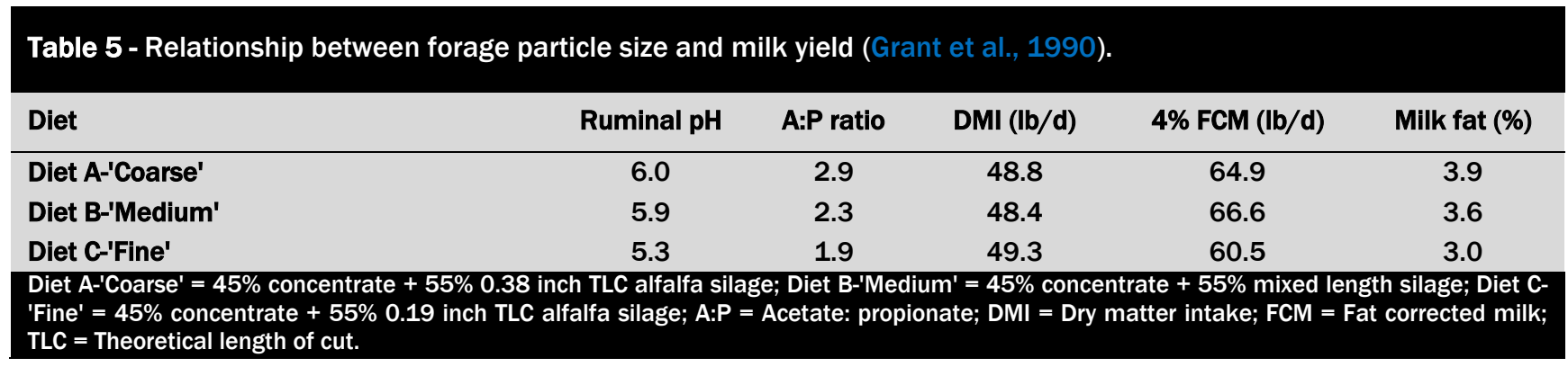

Feeding maize silage processed at adequate $(6 \mathrm{~mm}$; FCS $)$ or abrasive $(23 \mathrm{~mm}$; CCS) FPS were fed to 22 lactating Holstein cows had no effect on milk yield (Couderc et al., 2006). These results are partially in alignment with previous studies in previous experiments where reduced FPS did not influence milk yield in advanced lactating dairy cows (Armentano et al., 1988). It was hypothesized that, variation in total tract digestibility and variable retention time may partially compensate for the differences in nutrient intake and mask the lack of effects on milk yield (Couderc et al., 2006). Therefore, because the quality of the fat-corrected milk yield and the particulate passage rate measured were not impaired by the procedure, moderate genetic merit and high variability among the cows used in these studies may restrict the capacity of the cows to react to minor changes in nutritional intake or failure of the statistical model to detect variations in the experiment. Similarly, 16 mid-lactation Holstein dairy animals designated in a $4 \times 4$ Latin square design with a $2 \times 2$ arrangement were fed two distinctive chop lengths (shorter $=10 \mathrm{~mm}$ or longer $=19 \mathrm{~mm}$ ) of alfalfa silage and corn silage for a time of 21 days where treatments had no impact on milk yield (Bhandari et al., 2007). The absence of an effect of the FPS of alfalfa silage and corn silage on milk yield resembles earlier studies (Krause et al., 2002b) where alfalfa silage and corn silage exhibited no effect on milk yield. Similarly, corn silage at one-half milk-line stage of maturity and at $0.95-\mathrm{cm}$ theoretical length of cut without processing (control) or 0.95-, 1.45-, or 1.90-cm theoretical length of cut with processing at a 1-mm roll clearance had no effect on milk yield (Bal et al., 2000).

\section{Microbial protein synthesis}

Increasing peNDF content of diets decreased microbial protein synthesis (Li et al., 2020). Two principal factors impact ruminal digestion of forages, i.e., FPS and level of feed consumption (Firkins et al., 1986). Processing forages usually decreases ruminal fluid-phase dilution rate (D) but elevates particulate D (Weston and Hogan, 1967) and decreases extent of ruminal digestion (Blaxter et al., 1956; Hogan \& Weston, 1967). Accelerating feed consumption also results in quicker D (Grovum and Williams, 1977). Accumulative D of particulate or fluid digesta may aggravate efficiency of microbial protein synthesis (MPS) (Bergen et al., 1980). Consequently, FPS and, feed consumption may also affect efficiency of MPS. Studies evaluating effects of feed intake and forage processing in the same experiment (Alwash and Thomas, 1974; Beever et al., 1972) have indicated depressions in ruminal digestion of organic matter (OM) and fiber because of decreased ruminal retention times related with increased feed intake or smaller forage particle size. For ground hay, the digestibility of ADF in the rumen was lower but was partly accounted for by improved digestion of ADF in the hindgut. The duodenum feed flow plus endogenous nitrogen ( $\mathrm{N}$ ) was $37 \mathrm{Va}$ and $47 \mathrm{Vo}$ on $\mathrm{N}$ intake, respectively, with long and field hay. When field hay replaced long hay, MPS efficiency increased by $75 \mathrm{Va}$ and post-ruminal N digestion increased by $36 \mathrm{Vo}$. MPS efficiency was positively proportional to the rate of turnover of ruminal solids and inversely related to the rate of liquid dilution. These observations indicate increases in MPS efficacy with either increasing quantities of forage in the diet or improved solid ruminal passage (Rode et al., 1985).

\section{RUMEN PHYSIOLOGY}

\section{Rumen pH}

Four rumen-fistulated cows were randomly assigned in iso-energetic and iso-nitrogenous diets to study the effects of FPS on rumen pH (Rustomo et al., 2006). Expanding forage particle size at the same time increased the most extreme pH for dairy animals which demonstrated that coarse forage particle size can constrict drops in ruminal pH (Figures 5 and 6). In another experiment, expanding FPS increased eating time and decreased eating rate thus even hardly increased FPS was useful to mitigate decline of ruminal $\mathrm{pH}$ while profoundly fermentable carbohydrates were offered (Nasrollahi et al., 2014). Decreasing the FPS of corn silage improved rumen $\mathrm{pH}$ at 4-5 $\mathrm{h}$ after feeding ranging 6.12 to 6.20 (Bhandari et al., 2008).

\section{Ruminal fermentation}

The impacts of, and associations between, dietary grain source and moderate changes in alfalfa hay (AH) particle size (PS) on digestive processes of dairy cows were assessed (Nasrollahi et al., 2012). The results demonstrated that the minor increment of size of AH delayed eating time and improved rumen fermentation, in particular, feeding regimen in barley cereal. In another study, the peNDF substance of dairy cow eating regimens was altered by differing the FPS of alfalfa silage and impacts on ruminal fermentation (Li et al., 2020). Expanding FPS decreased VFA concentration in rumen. 


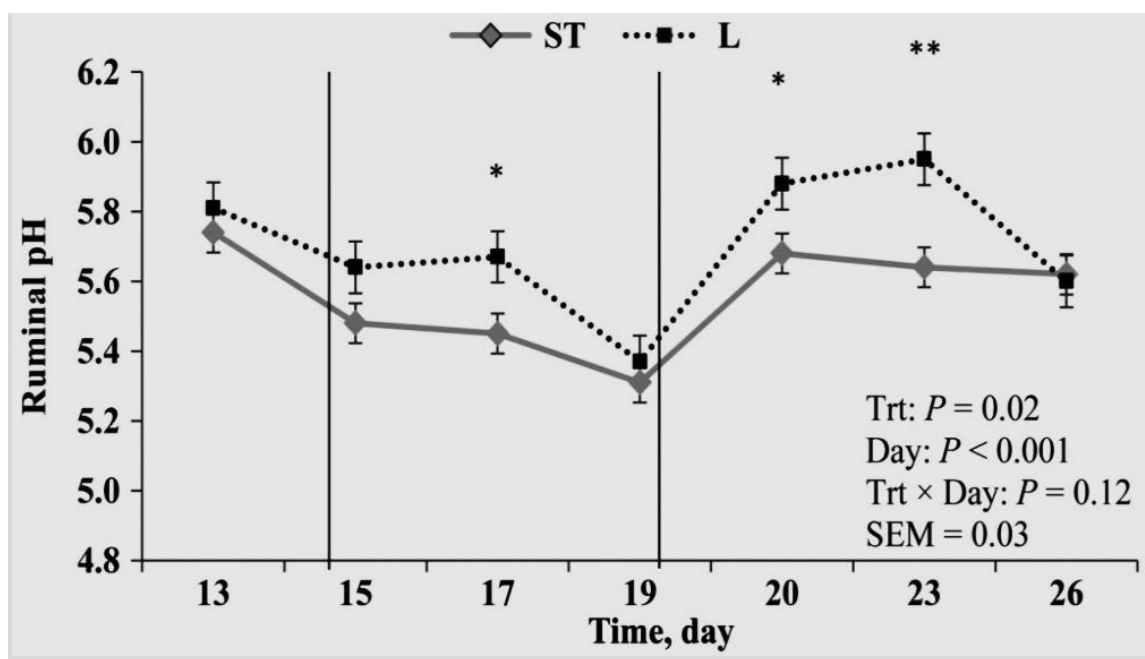

Figure 5 - Effect of rumen challenge on ruminal pH of dairy cows fed short (ST) or long (L) corn silage TMR (Kmicikewycz et al., 2015).

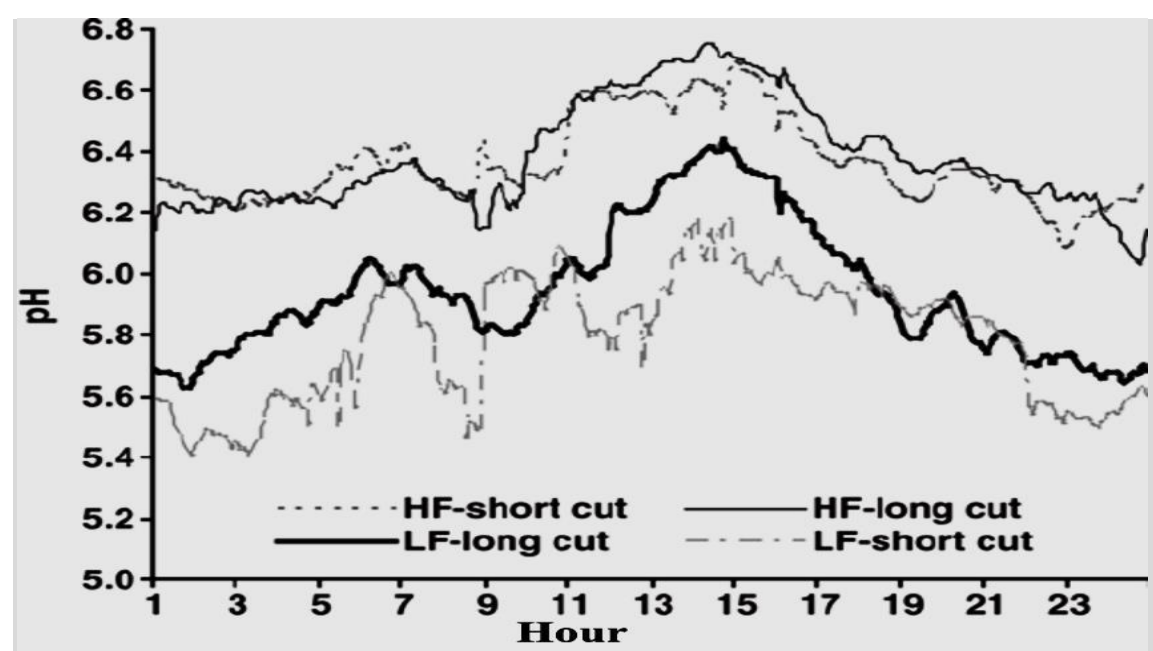

Figure 6 - Effects of forage particle length (short and long cut) on diurnal variation of ruminal pH. Feeding times were 0600, 1500, and $1800 \mathrm{~h}$, and the pH values were recorded every $5 \mathrm{~min}$ over a 48-h period (Yang \& Beauchemin, 2009).

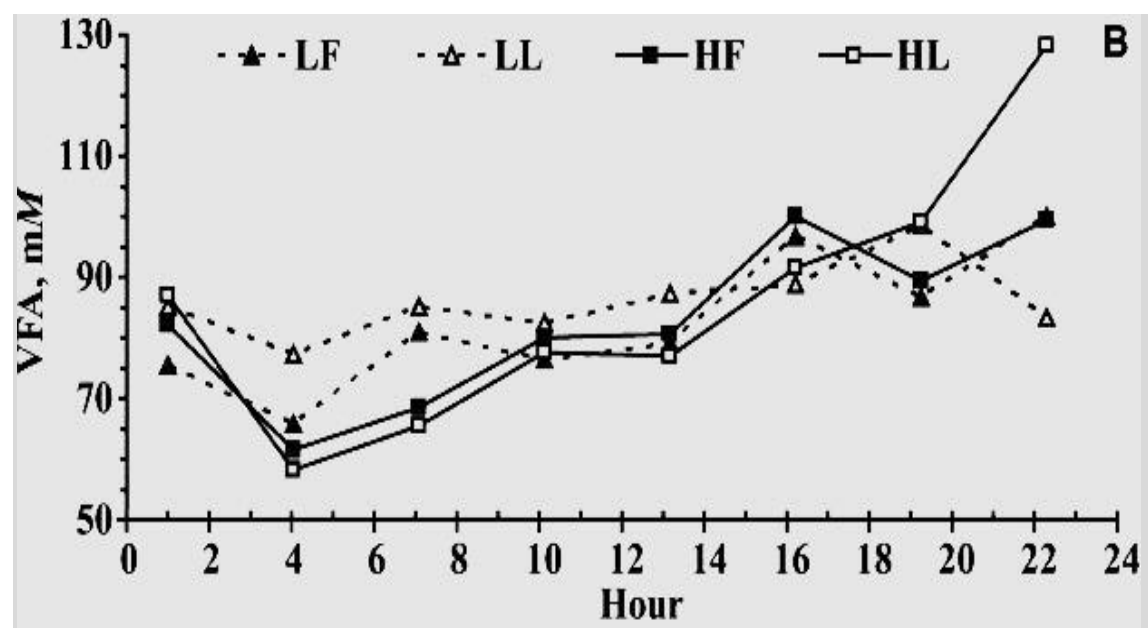

Figure 7 - Relationship between forage particle size and ruminal fermentation (Zebeli et al., 2007). LF = low concentrate level and fine hay; LL = low concentrate level and long hay; HF = high concentrate level and fine hay; HL = high concentrate level and long hay.

In alfalfa silage and corn silage based eating regimen, decreasing the chop length of alfalfa silage increased the concentrations of total VFA and the molar extent of acetic acid derivatives in rumen liquor yet did not influence the molar extents of propionate and butyrate and the acetic acid derivatives to propionate proportion (Bhandari et al., 2007). Indeed, the chop length of corn silage did not influence concentrations of total VFA, the molar extents of VFA, and the acetic acid derivatives to propionate proportion in the rumen. Maybe, lessening the FPS may have increased ruminal site of assimilation and VFA production because of increased surface area for microbial attack (Krause et al., 2002a). Likewise, lessening FPS can decrease saliva production and fluid passage rate (Krause et al., 2002a), in this manner 
increasing the concentrations of VFA in the rumen. Further, a decrease of FPS may likewise decrease VFA production (Figure 7) in the rumen because of increased particulate disappearance rate (Soita et al., 2003).

Like Krause et al. (2002b), Kononoff and Heinrichs (2003) found that a decrease of the FPS of hay silage increased the concentration of total VFA in rumen liquid. In any case, as opposed to this study, in these previous experiments, concentration of propionate increased more than that of acetic acid derivatives, which decreased the acetic acid derivatives to propionate proportion. Studies have detailed inconsistent outcomes on the impacts of the FPS of corn silage on rumen VFA. Similarly, it was found that decreasing the FPS of corn silage increased the concentration of total VFA in the rumen. Unlike VFA, decreasing the FPS of corn silage did not influence the rumen alkali concentration (Bhandari et al., 2007). Nevertheless, Kononoff and Heinrichs (2003) and Beauchemin and Yang (2005) did not find that a decrease of the FPS of alfalfa silage and corn silage influenced the outflow rate of fluid and particulate digesta from the rumen. Similarly, it was found that the FPS of corn silage did not influence rumen VFA (Kononoff \& Heinrichs, 2003).

\section{CONCLUSION}

Optimum forage particle size ensures maximum dry matter intake, reduced feed sorting, extended gut chewing and rumination activities in dairy cows. It further balances rumen $\mathrm{pH}$, ruminal fermentation, forage degradability, fractional passage kinetics of nutrients and feed effectiveness as a whole. Thus, microbial protein syntheses, body condition score of the host animal, milk yield and milk quality are accelerated. The overall impacts of particle size, however, depend on forage type, forage to concentrate ratio, and fermentability characteristics of the ration. In general, 8-19 $\mathrm{mm}$ particle size irrespective of forage type measured on Penn State Particle Separator may be considered optimum for practical dairy feed formulation.

\section{DECLARATIONS}

Corresponding Author

E-mail: emran@cvasu.ac.bd

\section{Authors' Contribution}

I am the sole contributor of the manuscript.

\section{Conflict of interests}

There is no any conflict of interest.

\section{Acknowledgements}

Department of Animal Science and Nutrition, Faculty of Veterinary Medicine, Chattogram Veterinary and Animal Sciences University, Zakir Hossain Road, Khulshi, Chattogram-4225, Bangladesh.

\section{Animal welfare statement}

No moral endorsement was required as this is a review article with no unique exploration of information.

\section{REFERENCES}

Allen MS (1997). Relationship between Fermentation Acid Production in the Rumen and the Requirement for Physically Effective Fiber. Journal of Dairy Science, 80(7): 1447-1462. https://doi.org/10.3168/jds.S0022-0302(97)76074-0.

Allen MS (2000). Effects of diet on short-term regulation of feed intake by lactating dairy cattle. Journal of Dairy Science, 83(7): 15981624. https://doi.org/10.3168/jds.S0022-0302(00)75030-2.

Alwash AH and Thomas PC (1974). Effect of the size of hay particles on digestion in the sheep. Journal of the Science of Food and Agriculture, 25(2): 139-147. https://doi.org/10.1002/jsfa.2740250205.

Armentano LE Pastore SC and Hoffman PC (1988). Particle Size Reduction of Alfalfa Silage Did Not Alter Nutritional Quality of High Forage Diets for Dairy Cattle. Journal of Dairy Science, 71(2): 409-413. https://doi.org/10.3168/jds.S0022-0302(88)79570-3.

Bal MA Shaver RD Jirovec AG Shinners KJ and Coors JG (2000). Crop processing and chop length of corn silage: Effects on intake, digestion, and milk production by dairy cows. Journal of Dairy Science, 83(6): 1264-1273. https://doi.org/10.3168/jds.S00220302(00)74993-9.

Beauchemin KA and Yang WZ (2005). Effects of physically effective fiber on intake, chewing activity, and ruminal acidosis for dairy cows fed diets based on corn silage. Journal of Dairy Science, 88(6): 2117-2129. https://doi.org/10.3168/jds.S0022-0302(05)72888-5.

Beever DE Coelho Da Silva JF Prescott JHD and Armstrong DG (1972). The effect in sheep of physical form and stage of growth on the sites of digestion of a dried grass: Sites of digestion of organic matter, energy and carbohydrate. British Journal of Nutrition, 28(3): 347-356. https://doi.org/10.1079/BJN19720044.

Bergen WG Bates DB Johnson DE Waller JC and Black JR (1980). Ruminal microbial protein synthesis and efficiency. Agricultural Economics Staff Paper-Michigan State University,

Bhandari SK Li S Ominski KH Wittenberg KM and Plaizier JC (2008). Effects of the chop lengths of alfalfa silage and oat silage on feed intake, milk production, feeding behavior, and rumen fermentation of dairy cows. Journal of Dairy Science, 91(5): 1942-1958. https://doi.org/10.3168/jds.2007-0358.

Bhandari SK Ominski KH Wittenberg KM and Plaizier JC (2007). Effects of chop length of alfalfa and corn silage on milk production and rumen fermentation of dairy cows. Journal of Dairy Science, 90(5): 2355-2366. https://doi.org/10.3168/jds.2006-609.

Blaxter KL Graham NM and Wainman FW (1956). Some observations on the digestibility of food by sheep, and on related problems. British Journal of Nutrition, 10(2): 69-91. https://doi.org/10.1079/bjn19560015. 
Couderc JJ Rearte DH Schroeder GF Ronchi Jl and Santini FJ (2006). Silage chop length and hay supplementation on milk yield, chewing activity, and ruminal digestion by dairy cows. Journal of Dairy Science, 89(9): 3599-3608. https://doi.org/10.3168/jds.S00220302(06)72399-2.

Deswysen A Vanbelle M and Focant M (1978). The effect of silage chop length on the voluntary intake and rumination behaviour of sheep. Grass and Forage Science, 33(2): 107-115. https://doi.org/10.1111/j.1365-2494.1978.tb00806.x.

DeVries TJ Beauchemin KA and Von Keyserlingk MAG (2007). Dietary forage concentration affects the feed sorting behavior of lactating dairy cows. Journal of Dairy Science, 90(12): 5572-5579. https://doi.org/10.3168/jds.2007-0370.

Dufreneix F Faverdin P and Peyraud J-L (2019). Influence of particle size and density on mean retention time in the rumen of dairy cows. Journal of Dairy Science, 102(4): 3010-3022.

Einarson MS Plaizier JC and Wittenberg KM (2004). Effects of barley silage chop length on productivity and rumen conditions of lactating dairy cows fed a total mixed ration. Journal of Dairy Science, 87(9): 2987-2996. https://doi.org/10.3168/jds.S00220302(04)73430-X.

Evans EW Pearce GR Burnett J and Pillinger SL (1973). Changes in some physical characteristics of the digesta in the reticulo-rumen of cows fed once daily. British Journal of Nutrition, 29(3): 357-376. https://doi.org/10.1079/bjn19730114.

Firkins JL Berger LL Merchen NR and Fahey GC (1986). Effects of forage particle size, level of feed intake and supplemental protein degradability on microbial protein synthesis and site of nutrient digestion in steers. Journal of Animal Science, 62(4): 1081-1094. https://doi.org/10.2527/jas1986.6241081x.

Grant RJ Colenbrander VF and Mertens DR (1990). Milk Fat Depression in Dairy Cows: Role of Silage Particle Size. Journal of Dairy Science, 73(7): 1834-1842. https://doi.org/10.3168/jds.S0022-0302(90)78863-7.

Grovum WL and Williams VJ (1977). Rate of passage of digesta in sheep: 6 . The effect of level of food intake on mathematical predictions of the kinetics of digesta in the reticulorumen and intestines. British Journal of Nutrition, 38(3): 425-436.

Gümüş H and Bayram i (2020). The effects of physically effective neutral detergent fibre content on growth performance and digestibility in beef cattle fed with total mixed ration. Kafkas Universitesi Veteriner Fakultesi Dergisi, 26(2): $157-163$. https://doi.org/10.9775/kvfd.2019.22582.

Haselmann A Zehetgruber K Fuerst-Waltl B Zollitsch W Knaus W and Zebeli Q (2019). Feeding forages with reduced particle size in a total mixed ration improves feed intake, total-tract digestibility, and performance of organic dairy cows. Journal of Dairy Science, 102(10): 8839-8849. https://doi.org/10.3168/jds.2018-16191.

Havekes CD Duffield TF Carpenter AJ and DeVries TJ (2020). Effects of wheat straw chop length in high-straw dry cow diets on intake, health, and performance of dairy cows across the transition period. Journal of Dairy Science, 103(1): $254-271$. https://doi.org/10.3168/jds.2019-17033.

Hogan J and Weston R (1967). The digestion of chopped and ground roughages by sheep II* The digestion of nitrogen and some carbohydrate fractions in the stomach and intestines. Australian Journal of Agricultural Research, 18(5): 803-819. https://doi.org/10.1071/AR9670803.

Jiang F Lin X Yan Z Hu Z Wang Y and Wang Z (2018). Effects of forage source and particle size on feed sorting, milk production and nutrient digestibility in lactating dairy cows. Journal of Animal Physiology and Animal Nutrition, 102(6): 1472-1481. https://doi.org/10.1111/jpn.12984.

Johnson TR and Combs DK (1992). Effects of inert rumen bulk on dry matter intake in early and midlactation cows fed diets differing in forage content. Journal of Dairy Science, 75(2): 508-519.

Kmicikewycz AD and Heinrichs AJ (2015). Effect of corn silage particle size and supplemental hay on rumen pH and feed preference by dairy cows fed high-starch diets. Journal of Dairy Science, 98(1): 373-385. https://doi.org/10.3168/jds.2014-8103.

Kmicikewycz AD Harvatine KJ and Heinrichs AJ (2015). Effects of corn silage particle size, supplemental hay, and forage-to-concentrate ratio on rumen $\mathrm{pH}$, feed preference, and milk fat profile of dairy cattle. Journal of Dairy Science, 98(7): $4850-4868$. https://doi.org/10.3168/jds.2014-9249.

Kononoff PJ and Heinrichs AJ (2003). The effect of reducing alfalfa haylage particle size on cows in early lactation. Journal of Dairy Science, 86(4): 1445-1457. https://doi.org/10.3168/jds.S0022-0302(03)73728-X.

Krause KM Combs DK and Beauchemin KA (2002a). Effects of forage particle size and grain fermentability in midlactation cows. I. Milk production and diet digestibility. Journal of Dairy Science, 85(8): 1936-1946. https://doi.org/10.3168/jds.S0022-0302(02)742707.

Krause KM Combs DK and Beauchemin KA (2002b). Effects of forage particle size and grain fermentability in midlactation cows. II. Ruminal pH and chewing activity. Journal of Dairy Science, 85(8): 1947-1957. https://doi.org/10.3168/jds.S0022-0302(02)742719.

Leonardi C Shinners KJ and Armentano LE (2005). Effect of different dietary geometric mean particle length and particle size distribution of oat silage on feeding behavior and productive performance of dairy cattle. Journal of Dairy Science, 88(2): $698-710$. https://doi.org/10.3168/jds.S0022-0302(05)72734-X.

Li C Beauchemin KA and Yang W (2020). Feeding diets varying in forage proportion and particle length to dairy cows: I. Effects on ruminal $\mathrm{pH}$ and fermentation, microbial protein synthesis, digestibility, and milk production. Journal of Dairy Science, 103(5): 4340-4354. https://doi.org/10.3168/jds.2019-17606.

Lu CD (1987). Implication of Forage Particle Length on Chewing Activities and Milk Production in Dairy Goats. Journal of Dairy Science, 70(7): 1411-1416. https://doi.org/10.3168/jds.S0022-0302(87)80163-7.

Maulfair DD Zanton GI Fustini M and Heinrichs AJ (2010). Effect of feed sorting on chewing behavior, production, and rumen fermentation in lactating dairy cows. Journal of Dairy Science, 93(10): 4791-4803. https://doi.org/10.3168/jds.2010-3278.

Méndez MN Chilibroste P and Aguerre M (2020). Pasture dry matter intake per cow in intensive dairy production systems: effects of grazing and feeding management. Animal, 14(4): 846-853.

Miller-Cushon EK Montoro C Bach A and DeVries TJ (2013). Effect of early exposure to mixed rations differing in forage particle size on feed sorting of dairy calves. Journal of Dairy Science, 96(5): 3257-3264. https://doi.org/10.3168/jds.2012-6415.

Nasrollahi SM Ghorbani GR Khorvash M and Yang WZ (2014). Effects of grain source and marginal change in lucerne hay particle size on feed sorting, eating behaviour, chewing activity, and milk production in mid-lactation Holstein dairy cows. Journal of Animal Physiology and Animal Nutrition, 98(6): 1110-1116. https://doi.org/10.1111/jpn.12185.

Nasrollahi SM Imani M and Zebeli Q (2015). A meta-analysis and meta-regression of the effect of forage particle size, level, source, and preservation method on feed intake, nutrient digestibility, and performance in dairy cows. Journal of Dairy Science, 98(12): 89268939. https://doi.org/10.3168/jds.2015-9681.

Nasrollahi SM Khorvash M Ghorbani GR Teimouri-Yansari A Zali A and Zebeli Q (2012). Grain source and marginal changes in forage particle size modulate digestive processes and nutrient intake of dairy cows. Animal, 6(8): 1237-1245. https://doi.org/10.1017/S1751731112000122. 
Omidi-Mirzaei H Azarfar A Mirzaei M Kiani A and Ghaffari MH (2018). Effects of forage source and forage particle size as a free-choice provision on growth performance, rumen fermentation, and behavior of dairy calves fed texturized starters. Journal of Dairy Science, 101(5): 4143-4157. https://doi.org/10.3168/jds.2017-13990.

Poppi DP Norton BW Minson DJ and Hendricksen RE (1980). The validity of the critical size theory for particles leaving the rumen. The Journal of Agricultural Science, 94(2): 275-280. https://doi.org/10.1017/S0021859600028859.

Ramirez Ramirez HA Harvatine KJ and Kononoff PJ (2016). Short communication: Forage particle size and fat intake affect rumen passage, the fatty acid profile of milk, and milk fat production in dairy cows consuming dried distillers grains with solubles. Journal of Dairy Science, 99(1): 392-398. https://doi.org/10.3168/jds.2015-10006.

Rode LM Weakley DC and Satter LD (1985). Effect of Forage Amount and Particle Size in Diets of Lactating Dairy Cows on Site of Digestion and Microbial Protein Synthesis. Canadian Journal of Animal Science, 65(1): 101-111. https://doi.org/10.4141/cjas85$\underline{011}$.

Rodríguez-Prado M Calsamiglia S and Ferret A (2004). Effects of fiber content and particle size of forage on the flow of microbial amino acids from continuous culture fermenters. Journal of Dairy Science, 87(5): 1413-1424. https://doi.org/10.3168/jds.S00220302(04)73290-7.

Rustas BO Nørgaard P Jalali AR and Nadeau E (2010). Effects of physical form and stage of maturity at harvest of whole-crop barley silage on intake, chewing activity, diet selection and faecal particle size of dairy steers. Animal, 4(1): 67-75. https://doi.org/10.1017/S1751731109990887.

Rustomo B Alzahal O Odongo NE Duffield TF and McBride BW (2006). Effects of rumen acid load from feed and forage particle size on ruminal $\mathrm{pH}$ and dry matter intake in the lactating dairy cow. Journal of Dairy Science, 89(12): $4758-4768$. https://doi.org/10.3168/jds.S0022-0302(06)72525-5.

Sharifi M Torbati NN Teimouri YA Hasani S and Ghorchi T (2012). Effect of corn silage particle size and level of soybean oil on ruminal mat composition, distribution and consistency in Zel sheep. African Journal of Biotechnology, 11(89): 15580-15589. https://doi.org/10.5897/ajb11.4332.

Shaver RD Nytes AJ Satter LD and Jorgensen NA (1988). Influence of Feed Intake, Forage Physical Form, and Forage Fiber Content on Particle Size of Masticated Forage, Ruminal Digesta, and Feces of Dairy Cows. Journal of Dairy Science, 71(6): $1566-1572$. https://doi.org/10.3168/jds.S0022-0302(88)79720-9.

Soita HW Christensen DA and McKinnon JJ (2003). Effects of barley silage particle size and concentrate level on rumen kinetic parameters and fermentation patterns in steers. Canadian Journal of Animal Science, 83(3): 533-539. https://doi.org/10.4141/A02-090.

Stojanović B G. Grubić Đorđević N Božičković A Davidović V and A. Ivetić (2013). Effects of Diet Physically Effective Fiber Content on Feeding Efficiency and Milk Production of Dairy Cows. In 10 $10^{\text {th }}$ International Symposium Modern Trends in Livestock Production www.istocar.bg.ac.rs

Storm AC and Kristensen NB (2010). Effects of particle size and dry matter content of a total mixed ration on intraruminal equilibration and net portal flux of volatile fatty acids in lactating dairy cows. Journal of Dairy Science, 93(9): 4223-4238. https://doi.org/10.3168/jds.2009-3002.

Suarez-Mena FX Lascano GJ and Heinrichs AJ (2013). Chewing activities and particle size of rumen digesta and feces of precision-fed dairy heifers fed different forage levels with increasing levels of distillers grains. Journal of Dairy Science, 96(8): 5184-5193. https://doi.org/10.3168/jds.2012-6155.

Ternouth JH (1968). the Rumen and Its Microbes. In Australian Veterinary Journal (Vol. 44, Issue 2) Academic Press, New York and London https://doi.org/10.1111/j.1751-0813.1968.tb04952.x.

Thomson AL Humphries DJ Kliem KE Dittmann MT and Reynolds CK (2017). Effects of replacing maize silage with lucerne silage and lucerne silage chop length on rumen function and milk fatty acid composition. Journal of Dairy Science, 100(9): 7127-7138. https://doi.org/10.3168/jds.2017-12914.

Voelker JA Burato GM and Allen MS (2002). Effects of pretrial milk yield on responses of feed intake, digestion, and production to dietary forage concentration. Journal of Dairy Science, 85(10): 2650-2661. https://doi.org/10.3168/jds.S0022-0302(02)74350-6.

Weston RH and Hogan JP (1967). The digestion of chopped and ground roughages by sheep. I. Movement of digesta through the stomach. Australian Journal of Agricultural Research, 18(5): 789-801.

Yang WZ and Beauchemin KA (2009). Increasing physically effective fiber content of dairy cow diets through forage proportion versus forage chop length: Chewing and ruminal pH. Journal of Dairy Science, 92(4): 1603-1615. https://doi.org/10.3168/jds.2008-1379.

Zebeli Q Tafaj M Weber I Dijkstra J Steingass H and Drochner W (2007). Effects of varying dietary forage particle size in two concentrate levels on chewing activity, ruminai mat characteristics, and passage in dairy cows. Journal of Dairy Science, 90(4): $1929-1942$. https://doi.org/10.3168/jds.2006-354.

Zebeli Q Tafaj M Weber I Steingass H and Drochner W (2008). Effects of dietary forage particle size and concentrate level on fermentation profile, in vitro degradation characteristics and concentration of liquid- or solid-associated bacterial mass in the rumen of dairy cows. Animal Feed Science and Technology, 140(3-4): 307-325. https://doi.org/10.1016/j.anifeedsci.2007.04.002.

Zhao YL Yan SM Beauchemin KA and Yang WZ (2020). Feeding diets varying in forage proportion and particle length to lactating dairy cows: II. Effects on duodenal flows and intestinal digestibility of amino acids. Journal of Dairy Science, 103(5): 4355-4366. https://doi.org/10.3168/jds.2019-17607. 